\title{
Effects of Calcium and Alginate Concentration on the Calcium-Deficient Hydroxyapatite Hydrogel Bead Formation
}

\author{
$\underline{\text { Armands Buss }^{1 *}, \text { Janis Locs }}{ }^{2}$
}

Rudolfs Cimdins Riga Biomaterials Innovations and Development Centre of RTU, Institute of General Chemical Engineering, Faculty of Materials Science and Applied Chemistry, Riga Technical University, Pulka 3, Riga, LV-1007, Latvia armands.buss@rtu.lv

\section{INTRODUCTION}

Natural gel-forming polymers represent an important class of biomaterials for immobilization applications. Among this class of polymers, alginate exhibits ability to undergo ionotropic gelation with bivalent ions, i.e., $\mathrm{Ca}^{2+}$, $\mathrm{Mg}^{2+}, \mathrm{Zn}^{2+}$ [1]. Alginate is a collective term for a family of copolymers containing 1,4-linked $\beta$ $\mathrm{D}$-mannuronic and $\alpha$-L-guluronic acid residues in varying proportions and sequential arrangements [2]. Alginate has been used for immobilization of various substances such as enzymes, food ingredients, proteins, drugs etc. This research project is focused on immobilization of calcium deficient hydroxyapatite (CDHAp) into Ca-alginate hydrogel and investigation of influence of $\left[\mathrm{Ca}^{2+}\right]$ and alginate ions on the bead formation process.

\section{EXPERIMENTAL METHODS}

CDHAp/Na-alginate $(\% \mathrm{w} / \mathrm{w})$ suspensions 15/1.5(A), 7.5/0.75(B), 5.0/0.5(C) were prepared according to the method [3]. $0.5 \mathrm{M}$ $\mathrm{Ca}\left(\mathrm{NO}_{3}\right)_{2}$ aqueous (aq) and ethanolic $(\mathrm{EtOH}$, $96.2 \% \mathrm{v} / \mathrm{v}$ ) solutions each were prepared and diluted further to obtain a range of $\left[\mathrm{Ca}^{2+}\right]$ solutions. Suspensions $A, B$ and $C$ were added dropwise to $\mathrm{Ca}^{2+}{ }_{(\mathrm{aq})}$ and $\mathrm{Ca}^{2+}{ }_{(\mathrm{EtOH})}$ solutions, using a syringe and a needle (Fig. 1).

\section{RESULTS AND DISCUSSION}

The experiment was conducted with an aim to demonstrate how the concentration affected the shape of the CDHAp beads. Gelation of the beads was modeled via proposed diffusion of $\mathrm{Ca}^{2+}$ through the alginate network (Eq.1) where $\mathrm{x}$, alginate suspension (A) contact time with $\left[\mathrm{Ca}^{2+}\right]$ in min and $\mathrm{f}(\mathrm{x})$, hydrogel length in $\mathrm{mm}$.

$f(x)=1.144 x^{0.447}$

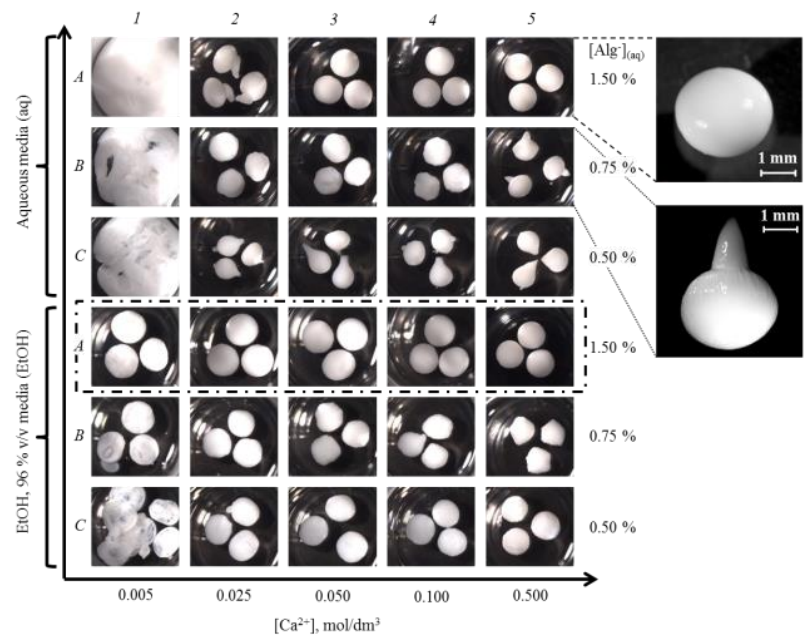

Fig. 1 Top view: CDHAp/Ca-alginate beads prepared from $\mathrm{Ca}\left(\mathrm{NO}_{3}\right)_{2(\text { aq })}$ and $\mathrm{Ca}\left(\mathrm{NO}_{3}\right)_{2(\mathrm{EtOH})}$ where $\left[\mathrm{Ca}^{2+}\right]$ was $\begin{array}{llllll}0.005 & 0.025, & 0.05, & 0.1, & 0.5 & \mathrm{M}\end{array}$ and $\left[\mathrm{Alg}^{-}\right]_{(\mathrm{aq})}$ in CDHAp/[Alg $]_{(\text {aq) }}$ was $0.50,0.75$ and $1.5 \% \mathrm{w} / \mathrm{w}$.

\section{CONCLUSION}

The most spherical beads were obtained with composition $A$ and $0.5 \mathrm{M}\left[\mathrm{Ca}^{2+}\right]_{(\mathrm{aq})}$. Factors affecting CDHAp/Ca-alginate bead shapes were the concentration of Na-alginate, $\mathrm{Ca}^{2+}$ and solvent properties. The content of CDHAp have insignificant influence on the shape. Further studies should be concluded to determine which shapes are most suited for use in biomaterials.

\section{REFERENCES}

[1] Yang C.H. et al., ACS Appl. Mater. Interfaces (2013),21:10418-10422

[2] Martinsen A. et al., Biotechnol. Bioeng. (1989),33:79-89

[3] $\mathrm{Fu}$ Y.C. et al., Mater. Sci. Eng., C. (2008),28:1149-1158

\section{ACKNOWLEDGEMENTS}

This work has been supported by the MERA.NET within the project "Tough, Strong and Resorbable Orthopaedic Implants" (GoIMPLANT). 